\title{
PENGARUH KEDISIPLINAN TERHADAP HASIL BELAJAR MATEMATIKA SISWA KELAS VIII SMP NEGERI 35 MAKASSAR
}

\author{
Jusnani \\ SMP Negeri 35 Makassar \\ jusnaniasdar35@yahoo.co.id
}

\begin{abstract}
ABSTRAK
Matematika murupakan pelajaran yang dianggap sangat sulit dan momok menakutkan untuk sebagian orang. Pelajaran matematika akan mudah jika dikerjakan dan disukai oleh siswa itu sendiri. Kedisiplinan bisa membuat pelajaran matamatika bisa dianggap mudah oleh siswa. Tujuan dari penelitia ini yaitu untuk mengetahui besar pengaruh disiplin terhadap hasil belajar siswa kelas VIII SMP Negeri 35 Makassar. Metode yang digunakan adalah penelitian survei. Penelitian ini dilakukan di SMP Negeri 35 Makassar pada Kelas VII, dengan sampel sebanyak 95 orang. Hasil dari penelitian adalah disiplin berpengaruh pada hasil belajar matematika begitu juga sebaliknya. Kedisiplinan baik di sekolah maupun di luar akan berpengaruh terhadap hasil belajar matematika siswa.
\end{abstract}

Kata Kunci: Kedisiplinan, Matematika, Hasil Belajar

\section{PENDAHULUAN}

Pelajaran matematika merupakan satu satu mata pelajaran wajib yang akan di ujian nasionalkan. Sehingga bisa dikatakan mata pelajaran matematika merupakan mata pelajaran wajib bagi siswa Sekolah Menengah Pertama (SMP). Berdasarkan pengalaman peneliti dalam menghadapi siswa dalam proses belajar mangejar matematika, masih banyak siswa yang kurang disiplin dalam mengerjakan soal matematika.

Adanya proses belajar mengajar yang terjadi di kelas antara siswa dan gurudapat mengaktualisasi kemampuan yang dimiliki siswa. Kegiatan proses belajar mengajar, tidak hanya yang terjadi di dalam kelas, tapi bisa juga terjadi di luar kelas, lingkungan sekolah, dan lingkungan masyarakat. Kegiatan belajar mengajar yang mempunyai tujuan perubahan yang bersifat positif sehingga seseorang bisa kearah kedewasaan. Perubahan positif yaitu prestasi belajar yang menjadi inti dari proses pembelajaran. Hasil dari proses belajar mengajar yang dicapai dipengaruhi oleh beberapa faktor, baik internal maupun eksternal. Faktor 
internal yang memperngaruhi hasil belajar adalah minat, bakatatau kepribadian siswa. Sedangkan faktor eksternal disebabkan dari lingkungannya, sarana dan prasarana, sistem serta proses kegiatan belajar mengajar. Faktor eksternal bisa juga berupa kedisiplinan siswa. Kedisiplinan tidak hanya pada lingkungan sekolah tapi juga lingkungan masyarakat di luar sekolah.

Memperhatikan hasil belajar siswa berarti dapat mengetahui kemampuan dan kualitas siswa. Tinggi rendahnya prestasi siswa akan memberikan sumbangsih untuk masa depan siswa. Menurut Djamarah prestasi belajar adalah apa yang dapat diciptakan, hasil pekerjaan, hasil yang menyenangkan hati yang diperoleh dengan keuletan kerja

\section{TINJAUAN PUSTAKA}

\section{Hakikat Belajar}

Belajar merupakan suatu aktivitas pekerjaan untuk mencapai suatu tujuan yang positif. Defenisi belajar sangat beragam, dimana tergantung pendapat para ahli. Menurut Slameto (2012:2) yakni" belajar adalah suatu proses usaha yang dilakukan seseorang untuk memperoleh perubahan tangkah laku baik keseluruhan, sebagian dari hasil pengalaman pribadi dalam interaksi lingkungannya. Sedangkan Asmani (2009: 2), belajar adalah proses seseorang dalam mencari ilmu untuk mengubah diri kearah yang lebih baik, sesuai dengan tingkat ilmu yang ingin dicapai. Proses utama dalam belajar adalah mencari ilmuh. Pencarian ilmu bagi seseorang harus mengorbankan baik materi maupun material. Perubahan yang didapat dari pencarian ilmu adalah adanya peningkatan yang dihasilkan pada diri pribadi pada tingkat ilmu yang dipelajari. Suprayekti (2010:160) berpendapat bahwa belajar adalah kegiatan yang berproses dan merupakan unsur yang sangat fundamental dalam setiap jenjang pendidikan termasuk pendidikan tinggi. Jenjang pendidikan yang dimaksud adalah mulai dari jenjang pendidikan dasar yaitu Taman Kana-Kanak (TK), Sekolah Dasar(SD), selanjutnya jenjang sekolah menengah yaitu Sekolah Menengah Pertama (SMP/sederajat) dan Sekolah Menengah Atas (SMA/Sederajat) dan sekeloh tinggi yaitu Perguruan Tinggi/universitas/Institusi.

Menurut Sriyono (2011:114) belajar adalah proses aktivitas yang dilakukan manusia secara sadar dengan memperdayakan indra yang dimilikinya untuk mendapatkan perubahan tingkah laku, kemampuan, keterampilan maupun sifatsifat yang ada dalam dirinya kearah yang lebih baiksebagai hail dari pengalaman dan interaksi yang terjadi dalam lingkungannya. Belajar salah satu kegiatan sadar yang dilakukan manusia dengan memperdayakan seluruh npanca indra. Dalam belajar semua panca indra harus digunakan sebagai mana mestinya. Sehingga aktivitas belajar tidak terganggu.

Dari beberapa pendapat ahli dapat disimpulkan bahwa belajar adalah proses aktivitas manusia untuk mengarah ke yang lebih baik dari berbagai bidang ilmu yang dipelajari. 


\section{Prestasi belajar}

Kemampuan tiap siswa berbeda-beda. Kemampuan Intelektual siswa bisa mennetukan keberhasilan dalam prestasi belajar siswa. Kamus Besar Bahasa Indonesia, prestasi diartikan sebagai hasil yang telah dicapai dari apa yang telah dilakukan. Menurut Djamarah (1994: 20-21) prestasi adalah apa yang telah diciptakan, hasil pekerjaan, hasil yang menyenangkan hati yang diperoleh dengan jalan keuletan kerja. Sumadi Suryabrata membagi prestasi belajar menjadi dua bagian, yaitu: Pertama, Hasil belajar siswa adalah penguasaan kecakapan siswa yang diusahakan secara sengaja dalam waktu dan satuan bahan tertentu. Kedua, hasil belajar aalah perbedaan antara kecapakan awal dan akhir proses belajar mengajar.

Pada Kamus Besar Bahasa Indonesia prestasi belajar adalah penguasaan pengetahuan atau keterampilan yang dikembangkan oleh mata pelajaran, lazinnya ditunjunkan dengan nilai tes atau angka nilai yang diberikan oleh guru. (Deperteman pendidikan dan Kebudayaan 1999:787). Surtinah Tirtonegoro (43) mengemukakan bahwa prestasi belajar adalah penilaian hasil usaha kegiatan belajar yang dinyatakan dalam symbol, angka, huruf, maupun kalimat yang mencerminkan hasil yang sudah dicapai oleh setiap anak dalam periode tertentu.

Melihat pengertian dari prestasi belajar diatas penulis menyimpulkan bahwa prestasi belajar adalah hasil yang dicapai siswa pada proses belajar mengajar dalam waktu tertentu, dimana prestasi belajar pada umumnya diberikan dalam bentuk nilai (angka) dari guru kepada siswa. Penilaian ini berkaitan dengan sampai mana pengetahuan siswa terhadap materi yang telah disampaikan oleh guru.

\section{Matematika}

Pelajaran matematika merupakan momok yang sangat menakutkan bagis siswa. Ilmu matematika sebagai suatu ilmu dasar bagi semua kalangan. Memahami ilmu matematika merupaka upaya mengenal matematika itu sendiri, pemahaman terhadap matematika dengan anggapan bahwa matematika itu sulit, akan menjadi pandangan yang sulit pula, beda halnya jika pandangan kita berubah bahwa matematika itu mudah, maka matematika itu akan mudah. Dengan demikian kita harus sepakat bahwa matematika itu mudah, mulai dari orang tua, siswa dan guru itu sendiri.

Suhendri (2011:32) bahwa matematika adalah ilmu tentang bilangan, bangun, hubungan konsep dan logika dengan menggunakan Bahasa atau symbol dalam menyelesaikan beberapa masalah dalam kehidapan sehari-hari. Matematika adalah ilmu bilangan-bilangan yang menggunakan simbol. Dalam kehidupan sehari-hari hubungan konsep dan logika dengan menggunakan bahasa lambang atau simbol dapat menyelesaikan masalah kehidupan. "Siregar (2002:22) "bahwa matematika berkembang dari pikiran-pikiran manusia yang berhubungan dengan ide-ide, struktur-struktur dan konsep-konsep abstrak yang akhirnya dapat membantu dalam menginterprestasikan secara tepat berbagai ide dan kesimpulan". Matematika tidak berkembang dengan begitu saja. Metematika berkembang dari pikiranpikiran manusia yang berhubungan dengan ide, struktur dan konsep 
abstrak. Dari ide, struktur dan konsep tersebut akhirnya dapat membantu dalam menginterprestasikan secara tepat berbagai ide dan kesimpulan.

Berdasarkan pendapat-pendapat diatas, dapat disimpulkan bahwa matematika adalah ilmu yang mempelajari tentang bilangan, konsep-konsep dan struktur mencari hubungan-hubungan antara konsep-konsep dan struktur-struktur matematika itu dengan menggunakan lambang-lambang atau simbol-simbol, dalam mempelajarinya membutuhkan ketekunan dan ketelitian.

\section{Kedisiplinan}

Disiplin merupakan suatu kontrol diri dalam mengatur berbagai kegiatan individu itu sendiri. Kedisiplinan sendiri berasal dari kata dasar disiplin. Menurut John (2011) "discipline is training to act accordance with rules.", jika diartikan disiplin adalah melatih seseorang untuk bertindak sesuai aturan. Disiplin adalah kesadaran untuk makukan sesuai dengan peraturan yang berlaku dengan penuh tanggung jawab tanpa ada paksaan (Asy Mas'udi, 2000: 88). Kedisiplinan merupakan fungsi operatif manajeman untuk seluruh organisasi, baik itu sekolah dan individu sendiri. Prestasi belajar akan tinggi jika kedisiplinan juga tinggi. Patuh, hormat dan melaksanakan perintah orang tua juga termasuk disiplin. Melakukan sesuai aturan sistem yangn belaku juga termasuk disiplin. Menurut Sulistiyowati (2001: 3) agar seorang siswa dapat belajar dengan baik maka ia harus bersikap disiplin, terutama disiplin dalam hal-hal sebagai berikut:

a. Disiplin dalam menepati jadwal pelajaran. Bila seorang siswa mempunyai jadwal kegiatan belajar, ia harus menepati jadwal yang telah dibuatnya. Dalam hal ini jauh sebelumnya sudah diperintahkan untuk membuat jadwal belajar sesuai dengan jadwal pelajaran.

b. Disiplin dalam mengatasi godaan yang akan menunda waktu belajar. Bila seorang siswa sudah tiba waktunya untuk belajar kemudian diajak bermain oleh temannya, maka siswa tersebut harus dapat menolak ajakan temannya secara halus agar tidak tersinggung.

c. Disiplin terhadap diri sendiri. Siswa dapat menumbuhkan semangat belajar baik di sekolah maupun di rumah. Sekalipun siswa mempunyai rencana belajar yang baik akan tetap tinggal rencana kalau tidak adanya disiplin diri.

d. Disiplin dalam menjaga kondisi fisik agar selalu sehat dan fit dengan cara makan makanan yang bergizi dan berolahraga secara teratur. Disiplin dalam menjaga kondisi fisik sangat penting, kalau tidak akan mempengaruhi aktivitas sehari-hari. Misalnya seorang siswa sebelum berangkat sekolah harus sarapan dulu agar dapat mengikuti kegiatan belajar dengan baik.

Reisman and Payne (1987:239-241) mengemukakan startegi umum mendidiplinkan peserta didik sebagai berikut.

a. Konsep diri (self-concept) strategi ini menekankan bahwa setiap konsepkonsep dari peserta didik merupakan factor penting dari setiap perilaku. Untuk menumbuhkan konsep diri, guru disarankan bersikap empatik, menerima, hangat dan terbuka, sehingga peserta didik dapat mengeksplorasikan dan perasaan dalam memecahkan masalah. 
b. Ketrampilan berkomunikasi (communication skills): guru harus memilki ketrampilan komunikasi yang efektif agar mampu menerima semua perasaan, dan mendorng timbulnya kepatuhan peserta didik.

c. Konsekuensi-konsekuensi logis dan alami (natural and logical) perilakuperilaku yang salah terjadi karena peserta didik telah mengembangkan kepercayaan yang salah terhadap dirinya. Untuk itu guru disrankan, menunjukkan secara tepat tujuan perilaku yang salah, sehingga membantu peserta didik dalam mengatasi perilakunya.

d. Klarifikasi nilai: strategi ini dilakukan untuk membantu peserta didik dalam menjawab pertanyaan sendiri tentang nilai-nilai dan membentuk system nilainya sendiri.

e. Analisis transaksional: disarankan agar guru bersifat dewasa, terutama apabila berhadapan dengan peserta didik yang menghadapi masalah. Adapun macam disiplin berdasarkan.

Fungsi disiplin menurut Tulus Tu'u (2004:38) adalah

a. Menata kehidupan bersama. Disiplin berguna untuk menyadarkan seseorang bahwa dirinya perlu menghargai orang lain dengan cara mentaati dan mematuhi peraturan yang berlaku, sehingga tidak akan merugikan pihak lain dan hubungan dengan sesama menjadi baik dan lancar.

b. Membangun kepribadian pertumbuhan kepribadian seseorang biasanya dipengaruhi oleh faktor lingkungan. Disiplin yang diterapkan di masingmasing lingkungan tersebut memberi dampak bagi pertumbuhan kepribadian yang baik. Oleh karena itu, dengan disiplin seseorang akan terbiasa mengikuti, mematuhi aturan yang berlaku dan kebiasaan itu lama kelamaan masuk ke dalam dirinya serta berperan dalam membangun kepribadian yang baik. Oleh karena itu perilaku disiplin akan membentuk kedisiplinan sesorang.

c. Melatih kepribadian sikap, perilaku dan pola kehidupan yang baik dan berdisiplin terbentuk melalui latihan. Demikian juga dengan kepribadian yang tertib, teratur dan patuh perlu dibiasakan dan dilatih.

Melihat berbagai uraian para ahli tentang disiplin, penulis mengambil kesimpulan bahwa kedisiplinan wajib dimiliki oleh semua siswa dimana pun berada. Kedisiplinan bagi siswa berguna untuk meningkatkan prestasi belajar. Disiplin juga mendorong siswa untuk memberikn kotribusi pada siswa lainnya, keluarga dan masyarakat sekitaranya.

Menurut Atheva (2007: 57) orang yang disiplin memiliki ciri-ciri sebagai berikut:

1. Selalu menaati peraturan atau tata tertib yang ada.

2. Selalu melaksanakan tugas dan kewajiban yang diterimanya dengan tepat waktu.

3. Kehidupannya tertib dan teratur.

4. Tidak mengulur-ulur waku dan menunda pekerjaan. 
Kedisiplinan di sekolah memiliki fungsi tertentu. Kedisiplinan sekolah berfungsi sebagai alat pendidikan dan alat menyesuaikan dalam membentuk sikap dan tingkah laku yang baik, yang nantinya dapat digunakan juga dalam lingkungan keluarga maupun lingkungan masyarakat. Dengan demikian kedisipinan sebagai alat pendidikan adalah suatu tindakan, perbuatan yang dengan sengaja diterapkan untuk kepentingan pendidikan di sekolah. Tindakan atau perbuatan tersebut dapat berupa perintah, nasehat, larangan, harapan, dan hukuman atau sanksi. Kedisiplinan sebagai alat pendidikan diterapkan dalam rangka proses pembentukan, pembinaan dan pengembangan sikap serta tingkah laku yang baik. Sikap dan tingkah laku yang baik tersebut dapat berupa ijin, berbudi pekerti luhur, patuh, hormat, tenggang rasa, dan berdisiplin. Tujuan disiplin adalah mengarahkan anak agar mereka belajar mengenai hal-hal baik yang merupakan persiapan bagi masa dewasa, saat mereka sangat bergantung kepada disiplin diri (Rimm, 2003: 47).

Kegiatan pembelajaran di sekolah tentukah melalui proses yang sangat kompleks serta dipengaruhi oleh berbagai faktor. Agar proses belajar memperoleh hasil yang baik, maka perlu diperhatikan berbagai faktor yang dapat mempengaruhi hasil belajar. Keseluruhan faktor-faktor itu saling berhubungan antara satu sama lain. Ada beberapa faktor yang mempengaruhi hasil belajar siswa, di antaranya yaitu faktor eksternal seperti lingkungan siswa, sekolah, guru, dan ekonomi keluarga. Sedangkan faktor dari dalam diri siswa seperti faktor fisiologis, faktor psikologis yang meliputi intelegensi (kecerdasan), minat, dan bakat. Semua faktor tersebut sangatlah berpengaruh terhadap baik buruknya hasil belajar siswa.

\section{METODE PENELITIAN}

Pendekatan yang digunakan dalam penelitian ini adalah penelitian survey dengan jenis penelitian kuantitatif deskriptif. Penelitian ini dilakukan di SMP Negeri 35 Makassar pada kelas VII. Menurut Kerlinger dalam Riduwan(2010:49) bahwa "penelitian survei adalah penelitian yang dilakukan pada populasi besar maupun kecil, tetapi data yang dipelajari adalah data dari sampel yang diambil dari populasi tersebut, sehingga ditemukan kejadian-kejadian relatif, distribusi dan hubungan antar variabel sosiologis maupun psikologis". Munurut Sugiyono (2007:8) pola hubungan antara variabel yang akan diteliti tersebut selanjutnya disebut sebagai paradigma penelitian atau model penelitian/desain penelitian. Adapun desain penelitiannya adalah sebagai berikut:

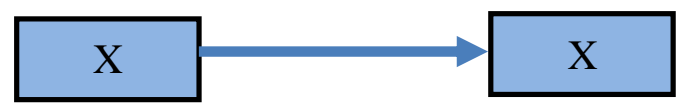

Gambar 1. Desain Penelitian

Keterangan:

X Kedisiplinan Siswa

Y: Prestasi Belajar Siswa 
Pada kasus penelitian ini yang menjadi Populasi adalah:

(1) Populasi target dalam penelitian ini adalah seluruh siswa dan siswi kelas SMP Negeri 35 Makassar tahun pelajaran 2018/2019 yang berjumlah 677 Orang.

(2) Populasi terjangkau adalah siswa dan siswi kelas SMP Negeri 35 Makassar tahun pelajaran 2018/20129 yang berjumlah 829 orang dengan rincian sebagai berikut:

Tabel 1. Jumlah siswa dan siswi kelas SMP Negeri 35 Makassar

\begin{tabular}{|c|c|l|l|l|}
\hline \multirow{2}{*}{ No } & \multirow{2}{*}{ Kelas } & \multicolumn{2}{|c|}{ Jumlah } & \multirow{2}{*}{ Jumlah } \\
\cline { 3 - 5 } & & Laki & Perempuan & \\
\hline 1 & VII & 145 & 138 & 283 \\
\hline 2 & VIII & 152 & 133 & 285 \\
\hline 3 & IX & 127 & 134 & 261 \\
\hline \multicolumn{2}{|l|}{ Jumlah seluruhnya } & 424 & 405 & 829 \\
\hline
\end{tabular}

Selanjutnya peneliti mengambil sampel pada kelas VIII dengan jumlah siswa sebanyak 95 orang. Menurut Supardi (2012:26) sampel adalah bagian dari populasiyang mempunyai ciri atau keadaan tertentu. Dalam penelitian kuantitatif sampel adalah subjek dari penelitian. sampel disini diambil $30 \%$ dari populasi. Teknik pengambilan sampel dalam tugas ini adalah teknik simple random sampling. Menurut Riduwan (2010:58) simple random sampling adalah cara pengambilan sampel dan anggota populasi dengan menggunakan acak tanpa memperhatikan strata (tingkatan) dalam anggota populasi tersebut. Populasi targetnya pada penelitian ini adalah siswa kelas VIII.

(3) Pada penelitian, peneliti menggunakan SPSS versi 25 for windows, sebagai aplikasi bantu untuk perhitungan data statistic.

\section{HASIL DAN PEMBAHASAN}

\section{a. Hasil Penelitian}

\section{Data Kedisiplinan}

Dari hasil pengukuran 95 siswa diketahui skor maksimum 184 dan skor minimum 132 dengan range 52. Dengan mean 156,14, median 156, modus 145, dan simpangan baku 11.027.

\section{Hasil Belajar Matematika}

Dari hasil pengukuran 95 siswa diketahui skor maksimum 93 dan skor minimum 50 dengan range 43 . Dengan mean 73,52, median 73, modus 80, dan simpangan baku 11,281.

\section{Pengujian Prasyarat}

\section{Uji normalitas}

Uji normalitas menggunakan aplikasi SPSS Versi 25 for Windows, dimana nilai sig sebagai patokan.

Jika nilai sig $>0,05$ maka data normal

Jika nilai sig $<0,05$ maka data tidak normal 
Tabel 2. Uji Normalitas

\begin{tabular}{|c|c|c|c|}
\hline \multicolumn{4}{|c|}{ One-Sample Kolmogorov-Smirnov Test } \\
\hline & & Kedisiplinan & Hasil_Belajar \\
\hline \multicolumn{2}{|l|}{$\mathrm{N}$} & 95 & 95 \\
\hline \multirow{2}{*}{$\begin{array}{l}\text { Normal } \\
\text { Parameters }\end{array}$} & Mean & 156.14 & 73.52 \\
\hline & Std. Deviation & 11.027 & 11.281 \\
\hline \multirow{3}{*}{$\begin{array}{l}\text { Most Extreme } \\
\text { Differences }\end{array}$} & Absolute & .078 & .117 \\
\hline & Positive & .078 & .083 \\
\hline & Negative & -.059 & -.117 \\
\hline \multicolumn{2}{|l|}{ Test Statistic } & .078 & .117 \\
\hline \multicolumn{2}{|c|}{ Asymp. Sig. (2-tailed) } & $.189^{\mathrm{C}}$ & $.053^{\mathrm{C}}$ \\
\hline \multicolumn{4}{|c|}{ a. Test distribution is Normal. } \\
\hline \multicolumn{4}{|c|}{ b. Calculated from data. } \\
\hline \multicolumn{4}{|c|}{ c. Lilliefors Significance Correction. } \\
\hline
\end{tabular}

Dari data di atas diketuhui nilai sig dari kedisiplinan sebesar 0,189 >0,05 berarti data kedisiplinan normal. Data tes hasil belajar pada data di atas sebesar $0,053>$ dari 0,05 , berarti data hasil belajar juga normal. Sehingga secara keseluruhan data setiap variabel berdistribusi normal, sehingga bisa dilakukan pengujian selanjutnya.

\section{Uji Linieritas}

Uji linieritas dilakukan untuk menguji apakah bentuk persamaan yang dihasilkan linier atau tidak. Pengujian dilakukan dengan menggunakan Tabel Ringkasan ANOVA,

Tabel 3. Hasil Tes Anova

\begin{tabular}{|c|c|c|c|c|c|c|c|}
\hline \multicolumn{8}{|c|}{ ANOVA Table } \\
\hline & & & $\begin{array}{l}\text { Sum of } \\
\text { Squares }\end{array}$ & df & $\begin{array}{l}\text { Mean } \\
\text { Square }\end{array}$ & $\mathrm{F}$ & Sig. \\
\hline \multirow{5}{*}{$\begin{array}{l}\text { Hasil_Belajar * } \\
\text { Kedisiplinan }\end{array}$} & \multirow{3}{*}{$\begin{array}{l}\text { Between } \\
\text { Groups }\end{array}$} & (Combined) & 3550.749 & 37 & 95.966 & .650 & .917 \\
\hline & & Linearity & 1.202 & 1 & 1.202 & .008 & .928 \\
\hline & & $\begin{array}{l}\text { Deviation from } \\
\text { Linearity }\end{array}$ & 3549.547 & 36 & 98.599 & .668 & .901 \\
\hline & \multicolumn{2}{|c|}{ Within Groups } & 8411.396 & 57 & 147.568 & & \\
\hline & \multicolumn{2}{|l|}{ Total } & 11962.145 & 94 & & & \\
\hline
\end{tabular}

Dari tabe Anova di atas dapat disimpulkan bahwa bahwa persamaan regresi yang dihasilkan memenuhi pola linear, karena nili sig >0,05 atau 0,901 >0,05. 


\section{Uji Hipotesis}

Uji hipotesis disini dilakukan untuk melihat apakah kedisiplinan berpengaruh terhadap hasil belajar. Jika berpengaruh berapa persen kedisiplinan terhadapat hasil belajar. Seperti uji normalitas dan linearitas, uji hipotesis juga menggunakan software atau aplikasi SPSS versi 25 for Windows. Hasil pengujian dapat dilihat pada tabel berikut:

\section{Tabel 3. Uji t}

\begin{tabular}{|c|c|c|c|c|c|c|}
\hline \multicolumn{7}{|c|}{ Coefficients $^{a}$} \\
\hline & & \multicolumn{2}{|c|}{$\begin{array}{l}\text { Unstandardized } \\
\text { Coefficients }\end{array}$} & \multirow{2}{*}{$\begin{array}{c}\text { Standardized } \\
\text { Coefficients } \\
\text { Beta } \\
\end{array}$} & \multirow[b]{2}{*}{$\mathrm{t}$} & \multirow[b]{2}{*}{ Sig. } \\
\hline \multicolumn{2}{|c|}{ Model } & B & Std. Error & & & \\
\hline \multirow[t]{2}{*}{1} & (Constant) & 71.922 & 16.604 & & 4.332 & .000 \\
\hline & Kedisiplinan & .010 & .106 & .010 & .097 & .000 \\
\hline
\end{tabular}

Dari data di atas dapat disimpulkan bahwa kedisiplinan berpengaruh terhadap hasil belajar matematika. Terlihat dari nilai sig. $<0,05$ yaitu $0,00<$ 0,05. Untuk melihat besar pengaruh kedisiplinan terhadap hasil belajar dapat dilihat pada tabel berikut ini:

\begin{tabular}{|l|c|r|r|r|}
\hline \multicolumn{5}{|c|}{ Model Summary $^{\mathbf{b}}$} \\
\hline Model & $\mathrm{R}$ & $\begin{array}{c}\mathrm{R} \\
\text { Square }\end{array}$ & $\begin{array}{c}\text { Adjusted R } \\
\text { Square }\end{array}$ & $\begin{array}{r}\text { Std. Error of } \\
\text { the Estimate }\end{array}$ \\
\hline 1 & $.010^{\mathrm{a}}$ & .357 & -.011 & 11.341 \\
\hline
\end{tabular}

Dari tabel di atas terlihat nilai R Square sebesar 0,357 atau 35,7\%. Nilai R Square ini menjadi patokan besar pengaruh kedisiplinan terhadap hasil belajar

\section{b. Pembahasan}

Berdasarkan penelitian yang telah dilakukan terhadap siswa di kelas VIII SMP Negeri 35 Makasssar dengan jumlah sampel 95 orang, dengan judul pengaruh kedisiplinan terhadap hasil belajar matematika siswa kelas VIII SMP Negeri 35 Makassar. Berdasarkan data yang diperoleh dari analisis data menggunakan SPSS versi 25 for windows. kedisiplinan siswa termasuk tinggi dengan nilai rata-rata sebesar 156,14, median 156,00, modus 145 dan simpangan baku 11,027 sehingga dapat disimpulkan bahwa hasil tes kedisipinan berada pada tingkat tinggi.

Hasil belajar matematika siswa termasuk dalam kategori sedang dengan ratarata 73,52, media 73, modus 80 dengan simpangan baku 11,281. Koefesien korelasi antara kedisiplinan siswa dengan hasil belajar siswa berada pada tingkat 
0,8674. Angka tersebut berada pada kategori kuat, sehingga dapat diartikan bahwa kedisiplinan memberikan pengaruh posisitf terhadap hasil belajar siswa yang kaut. Dimana nilai R Square sebesar 0,357 atau 35,7\%. Dengan kata lain kedisiplinan berpengaruh sebesar $35,7 \%$ terhadap hasil belajar matematika

\section{KESIMPULAN}

Berdasarkan data penelitian serta analisis data menggunakan SPSS Versi 25 For Windows, peneliti dapat menarik kesimpulan bahwa hasil belajar siswa dipengaruhi oleh kedisiplinan, begitu juga sebeliknya. Kedisiplinan siswa sangat mendukung untuk nilai hasil belajar matematika siswa. Untuk mencapai nilai matematika tinggi pada hasil belajar siswa diperlukan kedisiplinan yang tinggi dalam belajar maupun dalam kegiatan sehari-hari di sekolah

\section{DAFTAR PUSTAKA}

Asmani, Jamal Ma'mur. (2009). Jurus-jurus Belajar Efektif Untuk SMP dan SMA. Jogjakarta: DIVA Press.

Atheva, Abi. (2007). Perilaku Baik Sehari-hari. Semarang: CV Aneka Ilmu.

Djamarah, Syaiful Bahri. (2002). Prestasi Belajar dan Kompetensi Guru. Surabaya: Usaha Nasional.

John, Eltin. (2011). Upaya Meningkatkan Kedisiplinan Anak Di Kelas Melalui Cerita. Jurnal Pendidikan Penabur No. 16/ tahun ke-10 Juni.

Mas'udi, Asy. (2000). Pendidikan Pancasila Dan Kewarganegaraan. Yogyakarta: PT Tiga Serangkai.

Reisman and Payne. (1987). School Discipline. New York: Harper and Row Publishing.

Riduwan. (2010). Belajar Mudah Penelitian Untuk Guru-Karyawan dan Peneliti Pemula. Bandung:CV Alfabeta.

Rimm, Sylvia. (2003). Mendidik dan Menerapkan Disiplin pada Anakn Prasekolah. Jakarta: PT Gramedia Putaka Utama.

Siregar, Nurmaida Irawani. (2002). Pengaruh Pelatihan Sempoa (ABAKUS) Terhadap Prestasi Belajar Matematika. Tesis: Program Studi Pendidikan Minat Utama Psikologi Pendidikan Jurusan Ilmu-ilmu Sosial. Program Pasca Sarjana UGM Yogyakarta.

Slameto. (2010). Belajar dan Faktor-faktor yang Mempengaruhinya. Jakarta: PT Rineka Cipta.

Sriyono, Heru. (2011). Program Bimbingan Untuk Membantu Meningkatkan Kemandirian Belajar Siswa. Jurnal SOSIO e-KONS. Vol. III No.2 MeiJuli. Jakarta: Universitas Indraprasta PGRI.

Sugiyono. (2007). Statistika untuk Penelitian. Bandung:CV Alfabeta.

Suhendri, Huri. (2011). Pengaruh Kecerdasan Matematis-Logis Dan Kemandirian Belajar Terhadap Hasil Belajar Matematika. Jurnal Formatif 1(1): 29-39 ISSN: 2088-351X. Jakarta: Program Studi Pendidikan Matematika FTMIPA Universitas Indraprasta PGRI. 
Supardi. (2012). Aplikasi Statistika Dalam Penelitian: Buku Statistika Yang Paling Komprehensif. Jakarta: PT. Ufuk Publishing House.

Suprayekti. (2010). Keterampilan Belajar Mahasiswa. Jurnal Perspektif Ilmu Pendidikan. Vol. 22 Th. XIII Oktober. Jakarta:Fakultas Ilmu Pendidikan Negeri Jakarta.

Tirtonegoro,Surtinah.(1998).Anak Supernormal Dan Program Pendidikan. Jakarta: Rineka Cipta.

Tu'u Tulus. (2004). Peran Dsiplin pada perilaku daan prestasi siswa. Jakarta Grasindo 